ACTA UNIVERSITATIS WRATISLAVIENSIS

PRZEGLĄD PRAWA I ADMINISTRACJI CXX/1

WROCŁAW 2020

https://doi.org/10.19195/0137-1134.120.42

\author{
JERZY SUPERNAT \\ ORCID: 0000-0002-4590-0980 \\ Uniwersytet Wrocławski \\ Instytut Nauk Administracyjnych \\ Zakład Porównawczej Administracji Publicznej
}

\title{
PAŃSTWO ADMINISTRACYJNE
}

\begin{abstract}
Abstrakt: Termin „,państwo administracyjne” jest w Polsce raczej nieznany i nieużywany w kręgach teoretyków i praktyków administracji. Celem tekstu jest przypisanie mu określonego modelowego znaczenia, co powinno pozwolić wprowadzić termin ,państwo administracyjne” do języka administracji, a z państwa administracyjnego uczynić wyodrębniony przedmiot badań.
\end{abstract}

Słowa kluczowe: państwo, administracja, prawo administracyjne

Termin „państwo administracyjne” jest w Polsce raczej nieznany i stąd nieużywany przez przedstawicieli nauk administracyjnych ${ }^{1}$, a także przez pracowników administracji i osoby w jej otoczeniu. Powód tego wydaje się dość oczywisty i leży w negatywnych konotacjach terminu „państwo administracyjne”, wynikających z jego de facto pozornej bliskości z terminem „państwo biurokratyczne” w znaczeniu patologii państwa i jego administracji ${ }^{2}$. Przypisanie terminowi „pań-

${ }^{1}$ Zob. jednak J. Supernat, Administrative State in Comparative Perspective, [w:] Comparative Perspectives for Public Administration and Administrative Law, red. D. Cendrowicz, A. Chrisidu-Budnik, Wrocław 2018, s. 25 n.

2 Znamienny jest pierwszy przypis w pracy Nauka administracji, red. B. Kudrycka, B. Guy Peters, P.J. Suwaj, Warszawa 2009. Ponieważ autor Wstępu w tej pracy, B. Guy Peters, w oryginalnym anglojęzycznym tekście posługiwał się terminem bureaucracy, który w polskim tekście został zastąpiony terminem ,administracja publiczna”, w przypisie pierwszym znalazło się następujące wyjaśnienie: „Termin bureaucracy został przetłumaczony jako »administracja publiczna«, ponieważ w języku polskim słowo »biurokracja« wnosi negatywne konotacje, co nie było zamiarem autora" - ibidem, s. 19. Nota bene przyjęte thumaczenie w podręczniku akademickim nie znajduje uzasadnienia i należało pozostać przy terminie „biurokracja”, dodając ewentualnie wyjaśniający przypis. Potoczne stereotypowe rozumienie biurokracji w pracach naukowych jednoznacznie odrzucają M. Kulesza i D. Sześciło, Polityka administracyjna i zarządzanie publiczne, Warszawa 2013. Szeroko na temat właściwie rozumianej biurokracji zob. Biurokracja. Bureaucracy, red. J. Łukasiewicz, Rzeszów 2006. Z kolei na temat niewłaściwego rozumienia terminu „biurokracja” w kontekście przepisu mówiącego o skargach na „biurokratyczne załatwianie spraw” zob. J. Supernat, Biurokratyczne załatwianie spraw jako przedmiot 
stwo administracyjne" poprawnego modelowego znaczenia powinno umożliwić wprowadzenie go do języka administracji, a z państwa administracyjnego uczynić wyodrębniony przedmiot badań.

We właściwym neutralnym znaczeniu opisowym termin ,państwo administracyjne" został użyty ostatnio w książce The Administrative State ${ }^{3}$. W pracy tej Sabino Cassese przypisuje wynalezienie terminu „państwo administracyjne” amerykańskiemu politologowi Dwightowi Waldo ${ }^{4}$, co każe przypomnieć, że w Europie już na początku XX wieku mówiono o państwie niemieckim, iż staje się państwem administracyjnym, a jego poprzednik był nazywany państwem policyjnym (policja oznaczała administrację) - Polizeistaat ${ }^{5}$, a także państwem opiekuńczym - Wohlfahrtsstaat ${ }^{6}$. Innym państwem, które było nazywane państwem administracyjnym już na początku XX wieku, jest Austria ${ }^{7}$.

Warunkiem koniecznym wprowadzenia terminu „państwo administracyjne” do języka teorii i praktyki administracji jest ustalenie istotnych cech (znamion) przedmiotu, który nazywa, czyli państwa administracyjnego. Identyfikacja wybranych najważniejszych z nich jest celem tego artykułu. Ograniczenie się do tych kluczowych powinno zagwarantować abstrakcyjność, pozwalającą wyjść poza granice jednej jurysdykcji i zakreślić pojęcie państwa administracyjnego o ważności przynajmniej w państwach europejskich.

Pierwszą oczywistą i powszechną cechą państwa administracyjnego jest realizacja zadań publicznych (celów zadanych, czyli zadań właśnie), jako że państwo jest organizacją (organizacją państwową), a organizacje ze swej istoty są instrumentami osiągania celów ${ }^{8}$. Nota bene można twierdzić, że to zadania administracyjne przesądzają o kształcie większości rozwiązań prawnych składających się na prawo administracyjne ${ }^{9}$. W przypadku państwa administracyjnego chodzi

skargi powszechnej - uwagi de lege lata i de lege ferenda, [w:] Kodyfikacja postępowania administracyjnego. Na 50-lecie K.P.A., red. J. Niczyporuk, Lublin 2010, s. $771 \mathrm{n}$.

3 The Max Planck Handbooks in European Public Law, t. 1. The Administrative State, red. A. von Bogdandy, P.H. Huber, S. Cassese, Oxford 2017.

${ }^{4}$ Zob. S. Cassese, The Administrative State in Europe, [w:] The Max Planck Handbooks in European Public Law..., s. 58. Autor wskazuje pracę: D. Waldo, The Administrative State: A Study of the Political Theory of American Public Administration, New York 1948.

5 Zob. J.S. Langrod, Instytucje prawa administracyjnego. Zarys części ogólnej, Kraków 2003, passim, oraz F. Longchamps, Założenia nauki administracji, Wrocław 1949, passim. Warto dodać, że współczesne prawo administracyjne oparte na państwie prawa (Rechtsstaat) wyłoniło się z prawa policyjnego (Polizeirecht). Zob. A. von Bogdandy, P.M. Huber, Evolution and Gestalt of the German State, [w:] The Max Planck Handbooks in European Public Law..., s. 211.

${ }^{6}$ Zob. T. Bigo, Prawo administracyjne. Część ogólna (stenogram wykładów uniwersyteckich), wydał adw. dr J. Rodkowski, Lwów 1932, s. 24.

7 Zob. E. Wiederin, Evolution and Gestalt of the Austrian State, [w:] The Max Planck Handbooks in European Public Law..., s. 126.

8 Zob. między innymi C.C. Hood, Tools of Government, London 1983.

9 „Pierwszeństwo” zadaniom administracyjnym przed prawem administracyjnym przyznają H.C.H. Hofmann, G.C. Rowe, A.H. Türk: „Indeed, it is the activities or tasks of any public admini- 
o realizację publicznych zadań administracyjnych: administracja z zasady nie ma i nie może mieć żadnych własnych celów ${ }^{10}$. Rozrost tych zadań wiązał się z przekształceniem poddanego (administrowanego) w obywatela, a administracji z machiny (aparatu, maszynerii itp.) administracyjnej, wymuszającej posłuszeństwo poddanych, w administrację odpowiedzialną za świadczenie obywatelom usług (administracja władcza stała się administracją świadczącą). Ewolucja administracji i ekspansja jej zadań dokonały się w efekcie działań parlamentów krajowych i sądów. W przypadku parlamentów demokratyzacja zapewniła reprezentowanie w nich interesów całych społeczeństw, a nie tylko wybranych klas i grup, co zaowocowało nowymi regulacjami prawnymi kwestii społecznych, które poszerzyły obszar funkcjonowania administracji ${ }^{11}$. Z kolei sądy (wraz z parlamentami) ukształtowały funkcjonowanie administracji zgodnie z licznymi zasadami, a zwłaszcza zasadą praworządności (rządów prawa).

Drugą cechę państwa administracyjnego należy identyfikować w obszarze relacji między administracją i polityką. Państwo administracyjne jest państwem, w którym legitymacja administracji opiera się na demokratycznym reprezentatywnym parlamencie ${ }^{12}$. Oznacza to, że kardynalnym zadaniem administracji jest sprawne wykonywanie stanowionego przez parlament prawa (i przepisów wykonawczych) ${ }^{13}$.

stration which largely define, and indeed imply, the bulk of the legal arrangements - institutional structures, constraints, and controls - which go on to make up the applicable administrative law" - H.C.H. Hofmann, G.C. Rowe, A.H. Türk, Administrative Law and Policy of the European Union, Oxford 2011, s. 57.

10 Jeden z najnowszych polskich wykładów części ogólnej prawa administracyjnego otwiera rozdział poświęcony zadaniom publicznym z bezkompromisową oczywistą tezą: ,,[w] demokratycznym państwie prawnym rolą administracji publicznej jest [...] wykonywanie określonych prawem zadań publicznych" - A. Pakuła, Zadania administracji publicznej, [w:] Administracja. Prawo administracyjne. Część ogólna, red. J. Blicharz, L. Zacharko, Katowice 2018, s. 17-18. Przytoczone zdanie A. Pakuły przywodzi na myśl określenie administracji z pionierskiego artykułu W. Wilsona The Study of Administration z 1887 roku, zgodnie z którym „,dziedzina administracji jest odsunięta od pośpiechu i konfliktów polityki" (removed from the hurry and strife of politics), a administracja publiczna oznacza stosowanie zasad wydajności i ekonomii oraz racjonalnych technik zarządzania i organizacji w celu „szczegółowego i systematycznego wykonywania prawa publicznego" (detailed and systematic execution of public law), cyt. za: W.J. Novak, The Administrative State in America, [w:] The Max Planck Handbooks in European Public Law..., s. 118.

11 Na temat funkcji parlamentu zob. R. Balicki, Funkcja europejska Sejmu RP, Wrocław 2019, s. $19 \mathrm{n}$.

12 W konkretnym przypadku władze prawodawcza i wykonawcza są scalone (a separation of powers system based upon a fused legislative-executive), a codzienna praca parlamentu i funkcjonowanie władzy wykonawczej są zdominowane przez przywództwo partii dysponującej większością w parlamencie. System taki ma służyć politycznej wartości sprawnych rządów (the value of effective governance). Zob. J. Jowell, C. O'Cinneide, Values in the UK Constitution, [w:] An Inquiry into the Existence of Global Values. Through the Lens of Comparative Constitutional Law, red. D. Davis, A. Richter, C. Saunders, Oxford-Portland 2015, s. 388-389.

13 Oczywiście zawsze było jasne, że funkcja administracji nigdy nie wyczerpuje się w jurydycznym stosowaniu prawa — zwłaszcza dyskusja o uznaniu administracyjnym pokazuje, że stopień związania i zakres ograniczenia administracji prawem był i jest sporny. Nota bene koncepcja admi- 
Innymi słowy - państwo administracyjne jest państwem, w którym polityka administracyjna (polityka wobec administracji i polityka administracji ${ }^{14}$ ) jest podporządkowana rządom prawa i poddana sądowej kontroli. Kwestiami krytycznymi są tutaj determinacja prawna struktury i funkcjonowania administracji ${ }^{15}$, zakres przyznanego administracji uznania, korzystanie przez administrację z ogólnych zasad prawa i analogii oraz zakres deferencji sądów wobec działań administracji ${ }^{16}$.

Trzecią cechą państwa administracyjnego jest korzystanie z zawodowej służby cywilnej, zorganizowanej zgodnie z zasadami modelu biurokratycznego, co ma zapewnić jej stabilność, kompetencję, sprawność i neutralność ${ }^{17}$. Przy czym zasada (politycznej) neutralności administracji w poszczególnych państwach znajduje różne rozwiązania, ale bez jej przestrzegania nie można mówić o państwie administracyjnym.

Czwartą cechę państwa administracyjnego należy identyfikować w obszarze relacji między centrum i terenem. Państwo administracyjne jest państwem zintegrowanym (całością), w którym relacje między centrum i terenem mogą przyjmować różne rozwiązania, poczynając od znacznego scentralizowania i zhierarchizowania do form zdecentralizowanych, w tym samorządowych terytorialnych (zwłaszcza gminnych i regionalnych) ${ }^{18}$. Formy zdecentralizowane wymusza zwłaszcza wskazane powyżej wykonywanie w państwie administracyjnym coraz większej liczby zadań, których nie jest w stanie realizować (przeciążone) centrum.

Piątą cechą państwa administracyjnego jest działanie administracji zgodnie $\mathrm{z}$ uregulowanymi prawnie procedurami administracyjnymi ${ }^{19}$. Regulacja prawna

nistracji jako władzy (wyłącznie) wykonującej prawo jest nieadekwatna w przypadku administracji suprapaństwowej i międzynarodowej, jako że na przykład w Unii Europejskiej zadaniem unijnej administracji jest raczej stanowienie prawa niż jego wykonywanie. O Komisji Europejskiej J. Monnet mówił: ne fait pas; fait faire, cyt. za: S. Cassese, op. cit., s. 78.

14 Zob. J. Jeżewski, Polityka administracyjna. Zagadnienia podstawowe, [w:] A. Błaś, J. Boć, J. Jeżewski, Nauka administracji, red. J. Boć, Wrocław 2013, s. 312 n.

$15 \mathrm{Na}$,poluzowanie związków pomiędzy administracją a polityką, utożsamianą z parlamentem i rządem centralnym”, w kontekście niezależnych agencji regulacyjnych oraz decentralizacji i samorządu terytorialnego wskazuje R. Kusiak-Winter, Odpowiedzialność administracji publicznej. Struktura odpowiedzialności z perspektywy determinantów prawnych, Wrocław 2019, s. $116 \mathrm{n}$.

16 Krytycznie na temat deferencji w sądowej kontroli administracji w Polsce zob. Z. Kmieciak, J. Wegner, Deference to the Public Administration in Judicial Review: A Polish Perspective, [w:] Deference to the Administration in Judicial Review. Comparative Perspectives, red. G. Zhu, Springer 2019, s. 363 n.

17 Zob. między innymi Profesjonalizm w administracji publicznej, red. A. Dębicka, M. Dmochowski, B. Kudrycka, Białystok 2004, oraz Europa urzędników, red. Z. Brodecki, Warszawa 2009.

18 Kompleksową fundamentalną analizę rozwoju samorządu terytorialnego, w tym w państwie współczesnym, daje praca: I. Lipowicz, Samorzad terytorialny XXI wieku, Warszawa 2019.

$19 \mathrm{Na}$ temat procedur administracyjnych w organizacji suprapaństwowej zob. ReNEUAL Model Rules on EU Administrative Procedure, red. P. Craig et al., Oxford 2017, oraz J. Supernat, B. Kowalczyk, Kodeks postepowania administracji Unii Europejskiej, Warszawa 2017. Projekt rozporządzenia Parlamentu Europejskiego i Rady, stanowiący załącznik do Rezolucji Parlamentu Europejskiego z 9 czerwca 2016 roku w sprawie otwartej, efektywnej i niezależnej administracji 
procedur służy eliminacji arbitralności administracji i ma zapewnić jej sprawność, w tym przez wprowadzenie takich rozwiązań, jak przejrzystość, partycypacja i demokracja administracyjna ${ }^{20}$, sprawiedliwość administracyjna, sądowa kontrola administracji itd. Sprawność administracji w połączeniu z ochroną praw obywateli pozwala mówić o dobrej administracji (good administration) ${ }^{21}$. Podkreślenia wymaga znaczenie sądowej kontroli administracji, ponieważ w wielu państwach (między innymi we Francji i w Zjednoczonym Królestwie) sądowa kontrola decyzji administracyjnych mocno przyczyniła się do rozwoju prawa administracyjnego i w efekcie prawo administracyjne jest $w$ tych państwach prawem sędziowskim ${ }^{22}$.

Szóstą cechą państwa administracyjnego jest mocno rozwinięte prawo administracyjne ${ }^{23}$, kształtowane przez parlamenty, sądy i doktrynę ${ }^{24}$. Należy pod-

Unii Europejskiej (2016/2610 (RSP)), uznaje, że celem projektowanego rozporządzenia jest przyjęcie reguł proceduralnych służących zagwarantowaniu — jak mówi tytuł dokumentu — „otwartej, efektywnej i niezależnej administracji Unii Europejskiej”, a także właściwej egzekucji prawa do dobrej administracji.

${ }^{20}$ Partycypacja i demokracja administracyjna są źródłem dodatkowej legitymacji administracji oprócz legitymacji, jaką daje rzetelna realizacja prawa stanowionego przez parlament (legitymacja przez praworządność), a mianowicie legitymacji przez procedurę. Zwiększona dostępność administracji dla obywateli stwarza jednak ryzyko przechwycenia administracji przez interesy prywatne. Na temat demokracji administracyjnej zob. między innymi M. Wojtuń, W stronę demokracji administracyjnej - partycypacja w postępowaniu administracyjnym we Francji, [w:] Partycypacja w postępowaniu administracyjnym. W kierunku uspołecznienia interesu prawnego, red. Z. Kmieciak, Warszawa 2017, s. 93 n.

${ }^{21}$ Dualność rozumienia dobrej administracji można uznać za jeden z odwiecznych kanonów państwa administracyjnego. W Zjednoczonym Królestwie, w tak zwanym Raporcie Franksa z 1957 roku, który między innymi stwierdzał niedostatek formalnych procedur skargowych w wielu obszarach administracji publicznej, dwoistość dobrej administracji została określona w sposób, który eksponuje sprawność administracji z jednoczesnym przekonaniem ogółu społeczeństwa, że administracja działa $\mathrm{z}$ należytym uwzględnieniem równowagi pomiędzy interesem publicznym, który realizuje, i interesem prywatnym, który narusza, czyli — jakbyśmy dzisiaj powiedzieli z uwzględnieniem zasady proporcjonalności: „Administration must not only be efficient in the sense that the objectives of policy are securely attained without delay. It must also satisfy the general body of citizens that it is proceeding with reasonable regard to the balance between the public interest which it promotes and the private interest which it disturbs", cyt. za: Report of the Committee on Administrative Tribunals and Enquiries. Presented by the Lord High Chancellor to Parliament by Command of Her Majesty July 1957, London 1958, s. 5.

22 Zob. D. Dąbek, Prawo sędziowskie w polskim prawie administracyjnym, Warszawa 2010.

23 Poddanie administracji rządom prawa administracyjnego nie oznacza, że prawo administracyjne wyczerpuje prawo administracji. Zob. J. Jeżewski, Administracja pod rządem prawa cywilnego. $Z$ badań porównawczych nauki prawa administracyjnego, Wrocław 1974, passim. Wskazując, że zadaniem tej pracy było „zbadanie koncepcji, co do zjawiska, że pewna część administracji publicznej jest pod zarządem prawa cywilnego", M. Wierzbowski sformułował następującą refleksję: „przy takim założeniu praca powinna być traktowana jako cywilistyczna, co jednak w odbiorze doktryny nie nastąpiło" - M. Wierzbowski, Rozgraniczenie prawa administracyjnego i cywilnego, [w:] Cywilizacja administracji publicznej. Księga jubileuszowa z okazji 80-lecia urodzin Profesora Jana Jeżewskiego, red. J. Korczak, Wrocław 2018, s. 527.

${ }^{24} \mathrm{~W}$ niektórych systemach prawnych uznaje się, że organom administracyjnym przysługują kompetencje ogólne, pozwalające im podejmować działania, które nie są wyraźnie wymagane przez

Przegląd Prawa i Administracji CXX, 2020, cz. 1 i 2

(C) for this edition by CNS 
kreślić, że idea prawa administracyjnego jest dzisiaj akceptowana we wszystkich europejskich systemach prawnych, w tym w systemie common law ${ }^{25}$. Wszystkie one uznały, że władza publiczna i działanie publiczne nie mogą być arbitralne i wymagają stosowania określonych przepisów wykonawczych. Patrząc historycznie, prawo administracyjne dokonało $\mathrm{w}$ dojrzałych państwach transformacji tradycyjnej administracji przez przekształcenie poddanego w obywatela, któremu przysługują prawa wobec państwa. W efekcie administracyjne państwo prawa jest dzisiaj badane przez prawników. Jest tak zwłaszcza w Europie. W tych okolicznościach za niezrozumiałe i nieuzasadnione należy uznać przesunięcie nauk o administracji w nowej polskiej klasyfikacji dziedzin nauki i dyscyplin naukowych $\mathrm{z}$ nauk prawnych do nauk o polityce ${ }^{26}$.

Siódmą cechą (współczesnego) państwa administracyjnego jest jego zmienność, w tym zmienność administracji publicznej, którą zakładają i wymuszają zmieniające się polityki rządowe. W efekcie państwo administracyjne charakteryzuje dzisiaj nie stabilność, lecz dominacja reform administracyjnych ${ }^{27}$. Jedna z największych i powszechnych (nawet w krajach z różną kulturą administracyjną) reform administracyjnych ostatnich dekad była związana z (ponownym) odkryciem i afirmacją rynku i przekształceniem obywatela w konsumenta, co przyniosło zasadnicze przesunięcie reform administracyjnych z obszaru spraw wewnętrznych administracji do jej otoczenia w celu takiej modernizacji administracji, która pozwala poprawić jakość usług dla obywateli-konsumentów ${ }^{28}$.

Ósmą cechą państwa administracyjnego jest zmiana jego paradygmatu władczości, zwierzchności i jedności. Dzisiaj administracja nie tylko nakazuje, zakazuje i wymusza posłuszeństwo, ale także na przykład zachęca obywateli do realizacji określonych administracyjnych polityk i wytycznych ${ }^{29}$. Nie ma już także państwo

prawo. Jest tak na przykład w systemie francuskim w odniesieniu do działań władz lokalnych — zob. J.-B. Auby, The Transformation of the Administrative State and Administrative Law, [w:] The Max Planck Handbooks in European Public Law..., s. 608.

${ }^{25}$ W Zjednoczonym Królestwie jeszcze w latach siedemdziesiątych XX wieku istniało mocne przekonanie, że Brytania nie ma prawa administracyjnego. Zob. J. Supernat, Prawo administracyjne pod rzadami anglosaskiej myśli administracyjnej, [w:] Stan i kierunki rozwoju nauk administracyjnych, red. A. Błaś, J. Boć, Wrocław 2014, s. 93. Szeroko na temat rozwoju prawa publicznego w Zjednoczonym Królestwie zob. M. Loughlin, Evolution and Gestalt of the State in the United Kingdom, [w:] The Max Planck Handbooks in European Public Law..., s. 451 n.

26 Zob. załącznik do rozporządzenia Ministra Nauki i Szkolnictwa Wyższego z dnia 20 września 2018 roku w sprawie dziedzin nauki i dyscyplin naukowych oraz dyscyplin artystycznych, Dz.U. poz. 1818.

${ }^{27}$ Nie można natomiast zaprzeczyć ciągłości administracji, co pozwala mówić o zmienności w ciągłości.

${ }^{28}$ Zob. D. Sześciło, Rynek, prywatyzacja, interes publiczny. Wyzwania urynkowienia ushug publicznych, Warszawa 2014.

29 Zob. pionierską w Polsce pracę T. Kuty, Pojęcie działań niewładczych administracji. Na przyktadzie administracji rolnictwa, Wrocław 1963. 
zawsze przesądzającej pozycji nadrzędnej ${ }^{30}$. Zmiana tradycyjnego władczego paradygmatu administracji znajduje wyraz zwłaszcza w koncepcjach państwa dobrobytu, państwa regulacyjnego i państwa umożliwiającego obywatelom dokonywanie wyboru dostarczyciela usług, między innymi przez outsourcing świadczenia usług publicznych ${ }^{31}$. Nota bene odejście od paradygmatu władczości i związana z tym fragmentaryzacja administracji powodują, że unitarne państwo administracyjne nie ma unitarnej administracji.

Dziewiątą cechą państwa administracyjnego jest dzisiaj (nie tylko) w Europie jej kontekst pozapaństwowy. Zgodnie z tradycyjnym poglądem prawo administracyjne jest gałęzią prawa publicznego opartego na konstytucji32 i blisko połączonego z państwem narodowym. W efekcie wyłącznym kontekstem dla machiny administracyjnej było państwo narodowe. Sytuacja uległa zasadniczej zmianie, jako że poza państwem istnieją pozapaństwowe europejskie i globalne instytucje, które ustalają polityki, prawo i standardy dla administracji państwowych i monitorują ich implementację. W efekcie państwo utraciło wyłączną kontrolę nad polityką i prawem, a państwowa administracja jest agentem zarówno organów państwowych, jak i pozapaństwowych, co jest często źródłem różnych niepewności, napięć, a nawet konfliktów. W wymiarze doktrynalnym sytuacja zmniejszającego się powiązania administracji z kontekstem państwowym wymaga zmiany „państwowych" definicji administracji ${ }^{33}$ na definicje, które są jednocześnie państwowe i pozapaństwowe ${ }^{34}$.

30 Zwłaszcza Konstytucja Niemiec z 1949 roku przyniosła nową rolę państwa, zgodnie z którą państwo istnieje z uwagi na jednostkę, a nie jednostka z uwagi na państwo. Takie rozumienie relacji między jednostką i państwem oznacza rewolucję kopernikańską w prawie publicznym. Zob. A. von Bogdandy, P.H. Huber, op. cit., s. 196 n.

31 Zob. między innymi A. Chrisidu-Budnik, Od biurokracji do New Public Governance. Perspektywa izomorfizmu instytucjonalnego, Wrocław 2019.

32 O konstytucji mówi się jako o źródle prawa administracyjnego, a o prawie administracyjnym jako skonkretyzowanym prawie administracyjnym. Zob. L. Heuschling, The Complex Relationship Between Administrative and Constitutional Law, [w:] The Max Planck Handbooks in European Public Law..., s. 493 n. Przenikanie prawa administracyjnego przez prawo konstytucyjne ma istotne znaczenie dla sądowej kontroli administracji, jako że przesuwa punkt ciężkości ostatecznej kontroli działań administracji z sądów administracyjnych do sądów konstytucyjnych.

33 Do „państwowych” definicji administracji należy powszechnie znana definicja autorstwa J. Bocia, zgodnie z którą: „Administracja publiczna jest to przejęte przez państwo i realizowane przez jego zawisłe organy, a także przez organy samorządu terytorialnego zaspokajanie zbiorowych i indywidualnych potrzeb obywateli, wynikających ze współżycia ludzi w społecznościach" — J. Boć, Pojęcie administracji, [w:] Prawo administracyjne, red. J. Boć, Wrocław 2010, s. 15.

34 Oparta na „państwowej” definicji J. Bocia rozszerzona państwowa i pozapaństwowa definicja administracji mogłaby być następująca: Administracja publiczna jest to zaspokajanie zbiorowych i indywidualnych potrzeb mieszkańców, wynikających ze współżycia ludzi w społecznościach, przejęte przez państwo i realizowane przez jego zawisłe organy (centralne i lokalne) oraz przez jego organy samodzielne (zdecentralizowane agencje), a także — w ramach powierzenia — przez organy samorządu terytorialnego i organy organizacji pozapaństwowych (suprapaństwowych). 
Dziesiątą cechą państwa administracyjnego jest posiadanie systemu służącego przygotowaniu kadr dla administracji, w tym w postaci katedr uniwersyteckich prowadzących badania nad administracją państwową krajową, państwową zagraniczną i suprapaństwową (w tym europejską i globalną). W kontekście pozapaństwowym administracji należy przywołać art. 179 ust. 1 Traktatu o funkcjonowaniu Unii Europejskiej, który tworzy europejską przestrzeń badawczą (European research area) i art. 179 ust. 2 Traktatu, który mówi o umożliwieniu badaczom swobodnej współpracy ponad granicami (permitting researchers to cooperate freely across borders $)^{35}$. Ważne miejsce w europejskiej przestrzeni badawczej zajmuje utworzona w 2007 roku Europejska Rada do spraw Badań Naukowych (European Research Council) z jej agencją wykonawczą: European Research Council Executive Agency (ERCEA). Rozwiązania te mogą przynieść w przyszłości europejską wspólnotę naukową (European scientific/academic community). Wspólnota europejska wymaga, jak już wskazuje sama nazwa, odpowiedniej, to znaczy europejskiej tożsamości jej członków. Warto też zauważyć, że Carl Schmitt w 1950 roku przedstawił ideę wspólnej europejskiej nauki (wiedzy) prawnej jako prawnego źródła wspólnego (common) paneuropejskiego prawa, które ma przeciwdziałać politycznej interwencji w sferę prawa ${ }^{36}$.

Dokonana charakterystyka znamion państwa administracyjnego pozwala przypisać terminowi „państwo administracyjne” znaczenie, które jest na tyle operacyjne, że umożliwia podjęcie badań nad powstaniem i rozwojem państwa administracyjnego w Polsce, także porównawczo ${ }^{37}$, porządkujących już istniejący relewantny dorobek oraz ukazujących zachodzące nowe przemiany państwowości administracyjnej. Jest poza dyskusją, że jest to pole badań ważne i interesujące. Jednym z pierwszych efektów badań powinien być swoisty suplement do tomu pierwszego książki The Max Planck Handbooks in European Public Law pt. The Administrative State, w którym nie ma rozdziału o ewolucji i kształcie państwa

35 Za podręcznik europejskiej (unijnej) nauki administracji można uznać pracę: The Palgrave Handbook of the European Administrative System, red. M.W. Bauer, J. Trondal, New York 2015. Tak ją zresztą widzą redaktorzy i współautorzy M.W. Bauer, J. Trondal: „This volume is a primer on the European Union (EU) administrative system" - M.W. Bauer, J. Trondal, The Administrative System of the European Union, [w:] The Palgrave Handbook of the European Administrative System..., s. 1. Wartościowego przeglądu kierunków badawczych w zakresie administracji publicznej i zarządzania publicznego w Europie dokonali E. Ongaro et al., Public Administration and Public Management Research in Europe: Traditions and Trends, [w:] The Palgrave Handbook of Public Administration and Management in Europe, t. 1, red. E. Ongaro, S. van Thiel, London 2018, s. 11 n. Autorzy uwzględnili wiele (103) pozycji literaturowych, wśród których nie ma ani jednej polskiego autora.

${ }^{36}$ Ideę C. Schmitta przywołuje A. von Bogdandy, The Idea of European Public Law Today, [w:] The Max Planck Handbooks in European Public Law..., s. 4. Filozofia państwa i prawa C. Schmitta została ostatnio wspomniana z pewnym dystansem i ostrożnością w kontekście polskim przez A. Zolla — zob. Werdykt wyborczy może odwrócić rzekę. Z prof. Andrzejem Zollem rozmawia Maciej Stasiński, „Gazeta Wyborcza” 2018, nr 46 (9260), s. 24-25.

37 Zob. E.A. Young, Comparative Perspective, [w:] Oxford Principles of European Union Law. The European Union Legal Order, t. 1, red. R. Schütze, T. Tridimas, Oxford 2018, s. 142 n. 
administracyjnego w Polsce, zatytułowany w międzynarodowym języku tej pracy: The Administrative State in Poland. Do najważniejszych perspektyw badawczych w tym opracowaniu i w prowadzonych badaniach powinny należeć demokratyzacja, konstytucjonalizacja, jurydyzacja i profesjonalizacja państwa administracyjnego, a także jego funkcjonowanie w kontekstach europejskim i globalnym.

\section{ADMINISTRATIVE STATE}

\section{Summary}

The term 'administrative state' is rather unknown in Poland and therefore not used both by academia and public officials. The text aims to ascribe to this term specific model meaning, which should allow us to place the term 'administrative state' in the administrative language and make administrative state a distinct field of research.

Keywords: state, administration, administrative law

\section{BIBLIOGRAFIA}

Auby J.-B., The Transformation of the Administrative State and Administrative Law, [w:] The Max Planck Handbooks in European Public Law, t. 1. The Administrative State, red. A. von Bogdandy, P.H. Huber, S. Cassese, Oxford 2017, s. 601-630.

Balicki R., Funkcja europejska Sejmu RP, Wrocław 2019.

Bauer M.W., Trondal J., The Administrative System of the European Union, [w:] The Palgrave Handbook of the European Administrative System, red. M.W. Bauer, J. Trondal, New York 2015, s. 1-31.

Bigo T., Prawo administracyjne. Część ogólna (stenogram wykładów uniwersyteckich), wydał adw. dr J. Rodkowski, Lwów 1932.

Biurokracja. Bureaucracy, red. J. Łukasiewicz, Rzeszów 2006.

Boć J., Pojęcie administracji, [w:] Prawo administracyjne, red. J. Boć, Wrocław 2010, s. 12-16.

Bogdandy von A., The Idea of European Public Law Today, [w:] The Max Planck Handbooks in European Public Law, t. 1. The Administrative State, red. A. von Bogdandy, P.H. Huber, S. Cassese, Oxford 2017, s. 1-29.

Bogdandy von A., Huber P.H., Evolution and Gestalt of the German State, [w:] The Max Planck Handbooks in European Public Law, t. 1. The Administrative State, red. A. von Bogdandy, P.H. Huber, S. Cassese, Oxford 2017, s. 196-236.

Cassese S., The Administrative State in Europe, [w:] The Max Planck Handbooks in European Public Law, t. 1. The Administrative State, red. A. von Bogdandy, P.H. Huber, S. Cassese, Oxford 2017, s. 56-97.

Chrisidu-Budnik A., Od biurokracji do New Public Governance. Perspektywa izomorfizmu instytucjonalnego, Wrocław 2019.

Dąbek D., Prawo sędziowskie w polskim prawie administracyjnym, Warszawa 2010.

Europa urzędników, red. Z. Brodecki, Warszawa 2009.

Guy Peters B., Wstęp, [w:] Nauka administracji, red. B. Kudrycka, B. Guy Peters, P.J. Suwaj, Warszawa 2009, s. 19-25. 
Heuschling L., The Complex Relationship Between Administrative and Constitutional Law, [w:] The Max Planck Handbooks in European Public Law, t. 1. The Administrative State, red. A. von Bogdandy, P.H. Huber, S. Cassese, Oxford 2017, s. 493-556.

Hofmann H.C.H., Rowe G.C., Türk A.H., Administrative Law and Policy of the European Union, Oxford 2011.

Hood C.C., Tools of Government, London 1983.

Jeżewski J., Administracja pod rzadem prawa cywilnego. Z badań porównawczych nauki prawa administracyjnego, Wrocław 1974.

Jeżewski J., Polityka administracyjna. Zagadnienia podstawowe, [w:] A. Błaś, J. Boć, J. Jeżewski, Nauka administracji, Wrocław 2013, red. J. Boć, s. 298-322.

Jowell J., O'Cinneide C., Values in the UK Constitution, [w:] An Inquiry into the Existence of Global Values. Through the Lens of Comparative Constitutional Law, red. D. Davis, A. Richter, C. Saunders, Oxford-Portland 2015, s. 357-391.

Kmieciak Z., Wegner J., Deference to the Public Administration in Judicial Review: A Polish Perspective, [w:] Deference to the Administration in Judicial Review. Comparative Perspectives, red. G. Zhu, Springer 2019, s. 363-378.

Kulesza M., Sześciło D., Polityka administracyjna i zarządzanie publiczne, Warszawa 2013.

Kusiak-Winter R., Odpowiedzialność administracji publicznej. Struktura odpowiedzialności z perspektywy determinantów prawnych, Wrocław 2019.

Kuta T., Pojęcie działań niewładczych administracji. Na przykładzie administracji rolnictwa, Wrocław 1963.

Langrod J.S., Instytucje prawa administracyjnego. Zarys części ogólnej, Kraków 2003.

Lipowicz I., Samorzą terytorialny XXI wieku, Warszawa 2019.

Longchamps F., Zatożenia nauki administracji, Wrocław 1949.

Loughlin M., Evolution and Gestalt of the State in the United Kingdom, [w:] The Max Planck Handbooks in European Public Law, t. 1. The Administrative State, red. A. von Bogdandy, P.H. Huber, S. Cassese, Oxford 2017, s. 451-492.

The Max Planck Handbooks in European Public Law, t. 1. The Administrative State, red. A. von Bogdandy, P.H. Huber, S. Cassese, Oxford 2017.

Nauka administracji, red. B. Kudrycka, B. Guy Peters, P.J. Suwaj, Warszawa 2009.

Novak W.J., The Administrative State in America, [w:] The Max Planck Handbooks in European Public Law, t. 1. The Administrative State, red. A. von Bogdandy, P.H. Huber, S. Cassese, Oxford 2017, s. 98-124.

Ongaro E. et al., Public Administration and Public Management Research in Europe: Traditions and Trends, [w:] The Palgrave Handbook of Public Administration and Management in Europe, t. 1, red. E. Ongaro, S. van Thiel, London 2018, s. 11-39.

Pakuła A., Zadania administracji publicznej, [w:] Administracja. Prawo administracyjne. Część ogólna, red. J. Blicharz, L. Zacharko, Katowice 2018, s. 17-18.

Profesjonalizm w administracji publicznej, red. A. Dębicka, M. Dmochowski, B. Kudrycka, Białystok 2004.

ReNEUAL Model Rules on EU Administrative Procedure, red. P. Craig et al., Oxford 2017.

Report of the Committee on Administrative Tribunals and Enquiries. Presented by the Lord High Chancellor to Parliament by Command of Her Majesty July 1957, London 1958.

Supernat J., Administrative State in Comparative Perspective, [w:] Comparative Perspectives for Public Administration and Administrative Law, red. D. Cendrowicz, A. Chrisidu-Budnik, Wrocław 2018, s. 25-34.

Supernat J., Biurokratyczne załatwianie spraw jako przedmiot skargi powszechnej - uwagi de lege lata i de lege ferenda, [w:] Kodyfikacja postepowania administracyjnego. Na 50-lecie K.P.A., red. J. Niczyporuk, Lublin 2010, s. 771-773. 
Supernat J., Prawo administracyjne pod rzadami anglosaskiej myśli administracyjnej, [w:] Stan i kierunki rozwoju nauk administracyjnych, red. A. Błaś, J. Boć, Wrocław 2014, s. 93-102.

Supernat J., Kowalczyk B., Kodeks postępowania administracji Unii Europejskiej, Warszawa 2017.

Sześciło D., Rynek, prywatyzacja, interes publiczny. Wyzwania urynkowienia ustug publicznych, Warszawa 2014.

Waldo D., The Administrative State: A Study of the Political Theory of American Public Administration, New York 1948.

Werdykt wyborczy może odwrócić rzekę. Z prof. Andrzejem Zollem rozmawia Maciej Stasiński, „Gazeta Wyborcza" 2018, nr 46 (9260), s. 24-25.

Wiederin E., Evolution and Gestalt of the Austrian State, [w:] The Max Planck Handbooks in European Public Law, t. 1. The Administrative State, red. A. von Bogdandy, P.H. Huber, S. Cassese, Oxford 2017, s. 125-164.

Wierzbowski M., Rozgraniczenie prawa administracyjnego i cywilnego, [w:] Cywilizacja administracji publicznej. Księga jubileuszowa z okazji 80-lecia urodzin Profesora Jana Jeżewskiego, red. J. Korczak, Wrocław 2018, s. 525-528.

Wojtuń M., W stronę demokracji administracyjnej - partycypacja w postępowaniu administracyjnym we Francji, [w:] Partycypacja w postępowaniu administracyjnym. W kierunku uspołecznienia interesu prawnego, red. Z. Kmieciak, Warszawa 2017, s. 93-111.

Young E.A., Comparative Perspective, [w:] Oxford Principles of European Union Law. The European Union Legal Order, t. 1, red. R. Schütze, T. Tridimas, Oxford 2018, s. 142-190. 